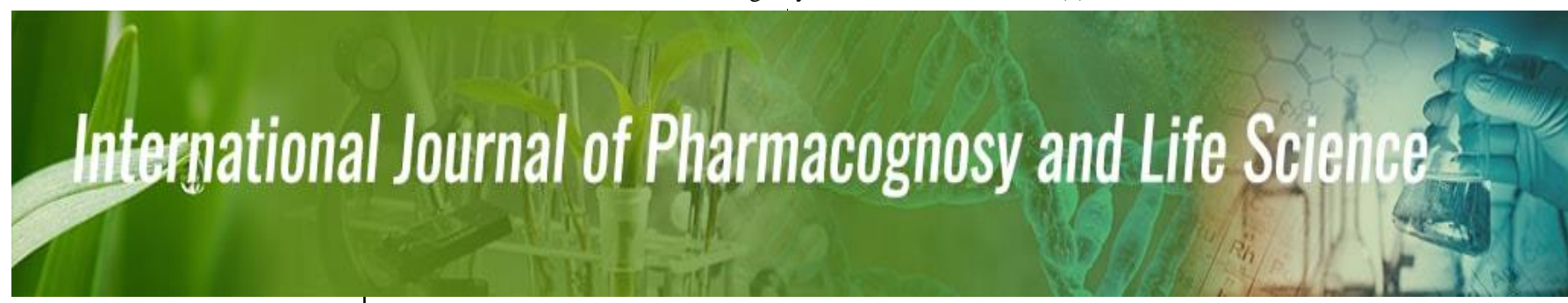

E-ISSN: 2707-2835

P-ISSN: 2707-2827

IJPLS 2020; 1(1): 10-15

Received: 07-11-2019

Accepted: 11-12-2019

\section{Talat Anjum}

Regional Ayurveda Research

Institute for Urinary

Disorders, CCRAS, Ministry of

AYUSH, Govt. Of India,

Jammu, India

Anupam K Mangal

Central Council for Research in

Ayurvedic Sciences (CCRAS),

Ministry of AYUSH, Govt. Of

India, New Delhi, India
Corresponding Author:

Talat Anjum

Regional Ayurveda Research

Institute for Urinary

Disorders, CCRAS, Ministry of

AYUSH, Govt. Of India

Jammu, India

\section{Therapeutic value of wild vegetables of Kashmir valley - Review}

\author{
Talat Anjum and Anupam K Mangal
}

DOI: $\underline{\text { https://doi.org/10.33545/27072827.2020.v1.i1a.3 }}$

\begin{abstract}
Wild vegetables have been the mainstay of human diets since times immemorial. There is an increasing consensus that wild foods could significantly contribute to alleviate hunger and cure diseases. Wild vegetables are receiving renewed attention as their potential human health benefits are being recognized. These are the cheapest and most readily available source of food that can contribute significantly to human nutrition and health as these are regarded as easily obtainable and palatable. Earlier people relied solely on wild plants as these were most abundant or readily available. With the advancement in agriculture, wild vegetables are underutilized, the present review documents therapeutic promise of 20 wild vegetables, which have remained an important part of the diet of Kashmiri people in India and are sources of potential therapeutic compounds, useful both for product development and awareness raising. These wild vegetables are generally good source of anti-oxidants, anti-carcinogenic, anti-microbial, hepato-protective, anti-diabetic, immuno-enhancing etc. Their promotion and integration into the human diets could assist in their protracted use and consequent health benefits. If these plant species continue to be neglected and underappreciated, knowledge about them may soon be lost in time and never be recovered. It is believed that there will be more dieticians rather than physicians in coming years as many diseases can be prevented and better health can be maintained by taking the right kind of food and nutrition which contains certain plants with specific functional attributes.
\end{abstract}

Keywords: wild vegetables, therapeutic, traditional medicine, health, naturopathy

\section{Introduction}

The rich plant diversity of the North Western Himalayas is utilized by the native communities in various forms as medicine, edible/food, fodder, fuel, timber, etc. Earlier people were dependent on the wild vegetables, with the advancement in agriculture and supply facilities, these non-cultivated plants are not a major component of the diet. A shift from intake of traditional food to contemporary food over past few decades has been attributed to the incidence of different diseases ${ }^{[52,61]}$. Unfortunately, the availability of some of the indigenous wild vegetables is decreasing owing to habitat destruction and population pressure. Additionally, many people are not aware of the nutritional value of such plants and regard them as inferior to use. Thus, wild vegetables are currently underutilized, and have been neglected. The multiple roles of wild traditional vegetables as both food and medicinal source have to be recognized as these are among the most important sources of natural antioxidants or for pharmaceutical applications against chronic diseases. The reintroduction of such plants may significantly contribute to human nutrition and health and may reduce the risk of diseases.

\section{Wild vegetables in traditional medicine of Kashmir.}

As in other parts of the world, wild vegetables have played an important role in traditional healthcare system of this region and have been used in alleviating and curing diseases. The root of Cichorium intybus L. is used for curing typhoid, enlargement of liver [36, 59]. Taraxacum officinale Weber, used as tonic, diuretic, blood purifier, in jaundice [58, 62]. Chenopodium foliosum Asch as laxative against jaundice and in urinary problems ${ }^{[62]}$. Malva sylvestris $\mathrm{L}$. for cough and fever ${ }^{[58]}$. P. lanceolata $\mathrm{L}$ as laxative, applied against boils, cough ${ }^{[58,62]}$. Oxyria dygyna (L.) Mill. for constipation, liver disorders and stomachache ${ }^{[62]}$. Rheum emodi Wall as vermicide, antiseptic on wounds and winter frost ${ }^{[58]}$. 
Dipsacus mitis D. Don, used in ritual bath after child birth and against sore throat ${ }^{[58]}$. Rumex nepalensis Spreng against fractured and dislocated joints ${ }^{[58]}$ the leaves and thorns of Centuria iberica L. used in burns, skin rashes, to improve eye vision and enhance lactation ${ }^{[63]}$ Leaves of Amaranthus caudatus L. used as expectorant, Nymphea Stellata Willd used as anti-periodic, cardiac stimulant, Plantago major L. leaves used as Styptic, Portulaca oleracea Roxb. Leaves used as styptic internally, Phytolaca acinosa Roxb. Root extract used against stomach cramps, dysentery, wound $s{ }^{[60]}$. Stems of Nelumbium nucifera Gaertn. used for fever, burning sensation, haematuria ${ }^{[55]}$.

\section{Therapeutic promise of wild vegetables}

The traditional wild vegetables have some medicinal value which makes them a valuable addition to the diet. Literature survey on the laboratory studies of these plants has shown that most of these plants have the anti-oxidant property followed by anti-inflammatory, antidiabetic, anticarcinogenic, anti-bacterial and hepatoprotective properties (Fig-1). The implication of oxidative stress in etiology of several chronic and degenerative diseases strongly favours that anti-oxidant therapy represents a promising avenue for treatment ${ }^{[54]}$

It is believed that with further research into the bioactive composition and mode of actions of the chemical contents of these documented plants, important lead compounds for the treatment of prevailing ailments may further emphasize their role for naturopathy in future.

Table 1: List wild vegetables with possible therapeutic use.

\begin{tabular}{|c|c|c|c|c|c|}
\hline $\begin{array}{l}\text { Sl. } \\
\text { no. }\end{array}$ & Botanical name & $\begin{array}{c}\text { Vernacular } \\
\text { name }\end{array}$ & Family & Part used & Therapeutic promise \\
\hline 1. & $\begin{array}{l}\text { Amaranthus caudatus } \\
\text { L. }\end{array}$ & Lissa & Amaranthceae & Leaf & Antioxidant $^{[1]}$, antimicrobial ${ }^{[2]}$, leaves an excellent source of protein ${ }^{[3]}$ \\
\hline 2. & Dipsacus mitis D.Don & Wopul haak & Dipsacaceae & Leaf & Anti-fertility and abortifacient ${ }^{[4]}$, against diarrhoea ${ }^{[5]}$ \\
\hline 3. & Malva parviflora $\mathrm{L}$. & Soutchal & Malvaceae & Leaf & Antibacterial and anti-inflammatory $^{[6]}$, antioxidant ${ }^{7}$ \\
\hline 4. & Malva sylvestris Linn & $\begin{array}{l}\text { Bagh- } \\
\text { soutchal }\end{array}$ & Malvaceae & Leaf & Antioxidant ${ }^{[8]}$, anti inflammatory ${ }^{[9]}$, antibacterial ${ }^{[9]}$ \\
\hline 5. & Nymphea alba & Khor & Nymphaceae & $\begin{array}{c}\text { Aerial } \\
\text { part }\end{array}$ & $\begin{array}{c}\text { Antibacterial }{ }^{[10]} \text {, calming, sedative for nervous system, useful in } \\
\text { treatment of insomnia and anxiety }\end{array}$ \\
\hline 6. & Nymphea stellata & Buem & Nymphaceae & Stem & Hepatoprotective ${ }^{[12]}$, anti-inflammatory, antidiabetic activity ${ }^{[13]}$, \\
\hline 7. & Plantago major & Wethe Gullae & Plantaginaceae & Leaf & $\begin{array}{c}\text { Wound healing activity, anti inflammatory, analgesic, antioxidant, weak } \\
\text { antibiotic, antiulcerogenic activity }{ }^{[14]}, \text { antiviral }{ }^{[15]}, \text { cytotoxic, } \\
\text { immunomodulatory }{ }^{[16]}\end{array}$ \\
\hline 8. & Portulaca oleracea & Nunar & Portulacaceae & Leaf & $\begin{array}{c}\text { Analgesic, anti-inflammatory }{ }^{[17]} \text {, wound healing }{ }^{[18]} \text {, antioxidant }{ }^{[19]} \text {, } \\
\text { antiulcerogenic }{ }^{[20]} \text {, muscle relaxant }{ }^{[21]} \text {, hepatoprotective }{ }^{[22]} \text {, against } \\
\text { abnormal uterine bleeding }{ }^{[23]}\end{array}$ \\
\hline 9. & Rumex nepalensis & Abuj & Polygonaceae & Leaf/Root & $\begin{array}{c}\text { Purgative }{ }^{[24]} \text {, antifungal }{ }^{[25]} \text {, antibacterial }{ }^{[26]} \text {, cytotoxic }{ }^{[27]} \text {, anti- } \\
\text { inflammatory, free radical scavenging activity } \\
\text { antioxidant }{ }^{[30]}\end{array}$ \\
\hline 10. & $\begin{array}{l}\text { Taraxacum officinale } \\
\text { Weber. }\end{array}$ & Handh & Asteraceae & Leaf & $\begin{array}{l}\text { Anti-inflammatory }{ }^{[31]} \text {, choleretic, anti-inflammatory, anti-oxidative, } \\
\text { anti-carcinogenic, analgesic, antihyperglycemic, anti-coagulatory } \\
\text { prebiotic effects }{ }^{[32]} \text {, diuretic, }{ }^{[33]} \text { antioxidant, hepatoprotective }{ }^{[34]}\end{array}$ \\
\hline 11. & $\begin{array}{l}\text { Rheum emodii Wall. } \\
\quad \text { ex Meisn }\end{array}$ & Pamb Haak & Polygonaceae & Leaf/Root & $\begin{array}{c}\text { Diuretic, liver stimulant, purgative, cathartic, stomachic, } \\
\text { anticholesterolaemic, antitumour, antiseptic, antifungal, anti-microbial, } \\
\text { anti-Parkinson's, anti-proliferative, immuno-enhancing, antiviral and } \\
\text { antioxidant }{ }^{[35]}\end{array}$ \\
\hline 12. & Cichorium intybus $\mathrm{L}$. & Kasni handh & Asteraceae & $\begin{array}{l}\text { Leaf } \\
\text { Root }\end{array}$ & Skin diseases, enlargement of Liver ${ }^{[36]}$, antibacterial ${ }^{[57]}$. \\
\hline 13. & Centuria iberica $\mathrm{L}$. & Krtisch & Asteraceae & Leaf & Burns, skin rashes, eye vision and defective lactation ${ }^{[37]}$ \\
\hline 14. & $\begin{array}{c}\text { Nelumbium nucifera } \\
\text { Gaertn. }\end{array}$ & Nodur & Nelumbonaceae & $\begin{array}{c}\text { Stem / } \\
\text { Rhizome }\end{array}$ & $\begin{array}{c}\text { Hypoglycemic, psychopharmacological effect, }{ }^{[36]} \text { demulcent, beneficial } \\
\text { in dysentery and chronic dyspepsia }{ }^{[38]}\end{array}$ \\
\hline 15. & $\begin{array}{l}\text { Chenopodium } \\
\text { foliosum Asch. }\end{array}$ & Wan palak & Chenopodiaceae & \begin{tabular}{c|}
$\begin{array}{c}\text { Aerial } \\
\text { part }\end{array}$ \\
\end{tabular} & antimicrobial activity ${ }^{[39]}$, radical-scavenging activity ${ }^{[40]}$ \\
\hline 16. & Atriplex hotensis & Wasta haak & Chenopodiaceae & & Antioxidant activity ${ }^{[41]}$, diuretic, emetic and purgative ${ }^{[42]}$ \\
\hline 17. & Phytolaca acinosa & Lober haak & Phytolacaceae & Leaf & Antioxidant activity ${ }^{[43]}$ \\
\hline 18. & Plantago lanceolata & Gulle & Plantaginaceae & Leaf & $\begin{array}{l}\text { Antioxidant and anti carcinogenic }{ }^{[44,45]} \text {, anti-inflammatory and } \\
\text { cytotoxic }{ }^{[46]}\end{array}$ \\
\hline 19. & Rumex acetosa & Tchok chen & Polygonaceae & Leaf & Antimutagenic and cytotoxic ${ }^{[50]}$ \\
\hline 20. & Oxyria digyna & Churboo & Oxalidaceae & Leaf & Antioxidant activity ${ }^{[51]}$ \\
\hline
\end{tabular}




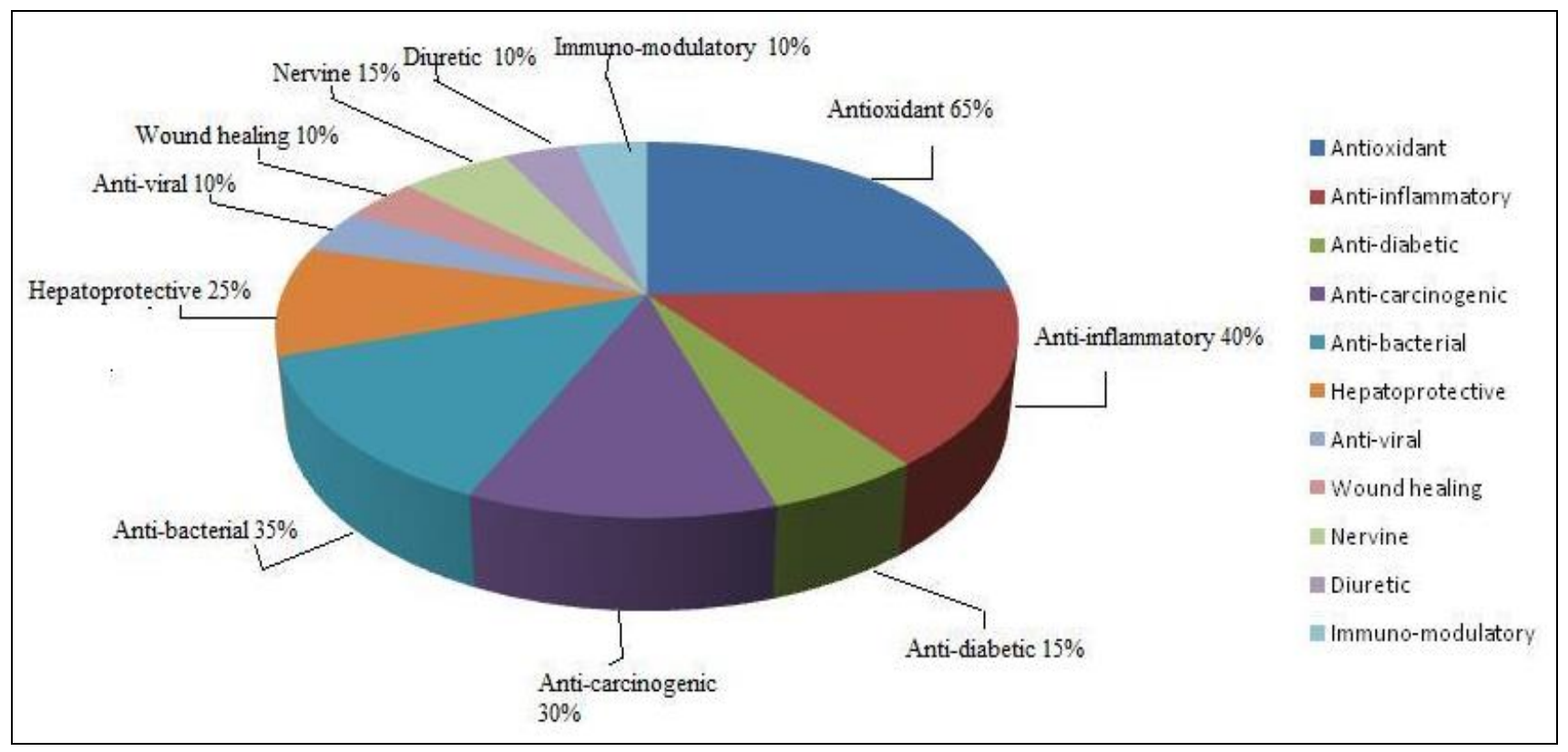

Fig 1: Wild vegetables as therapeutic s

Out of the twenty wild vegetables chosen for study in the present review, there is fairly good number of plants with potential therapeutic properties which can be exploited for healthcare (Fig-2). There are about 13 plants like Amaranthus caudatus L., Malva spp., Plantago spp., Portulaca oleracea Roxb. etc., which possess impressive anti-oxidative properties. About eight plants possess antiinflammatory properties. Likewise 6-8 plants have anticancer and other properties. 2-4 plants have either diuretic or liver protectant, vision enhancing or nervine attributes (Fig-2). The prevalence of cancers have been attributed to diet. ${ }^{[52,53,61]}$ The search for anticancer plants, particularly those which have remained a part of the diet once is on increase. Heo et al. (2009) investigated that Rumex acetosa have potential anti-proliferative properties. Nelumbium nucifera Gaertn. has been studied to have psychopharmacological properties ${ }^{[36]}$. The consumption of wild vegetables may provide millions of consumers with the nutrients needed to maintain health and fight off hazardous infections.

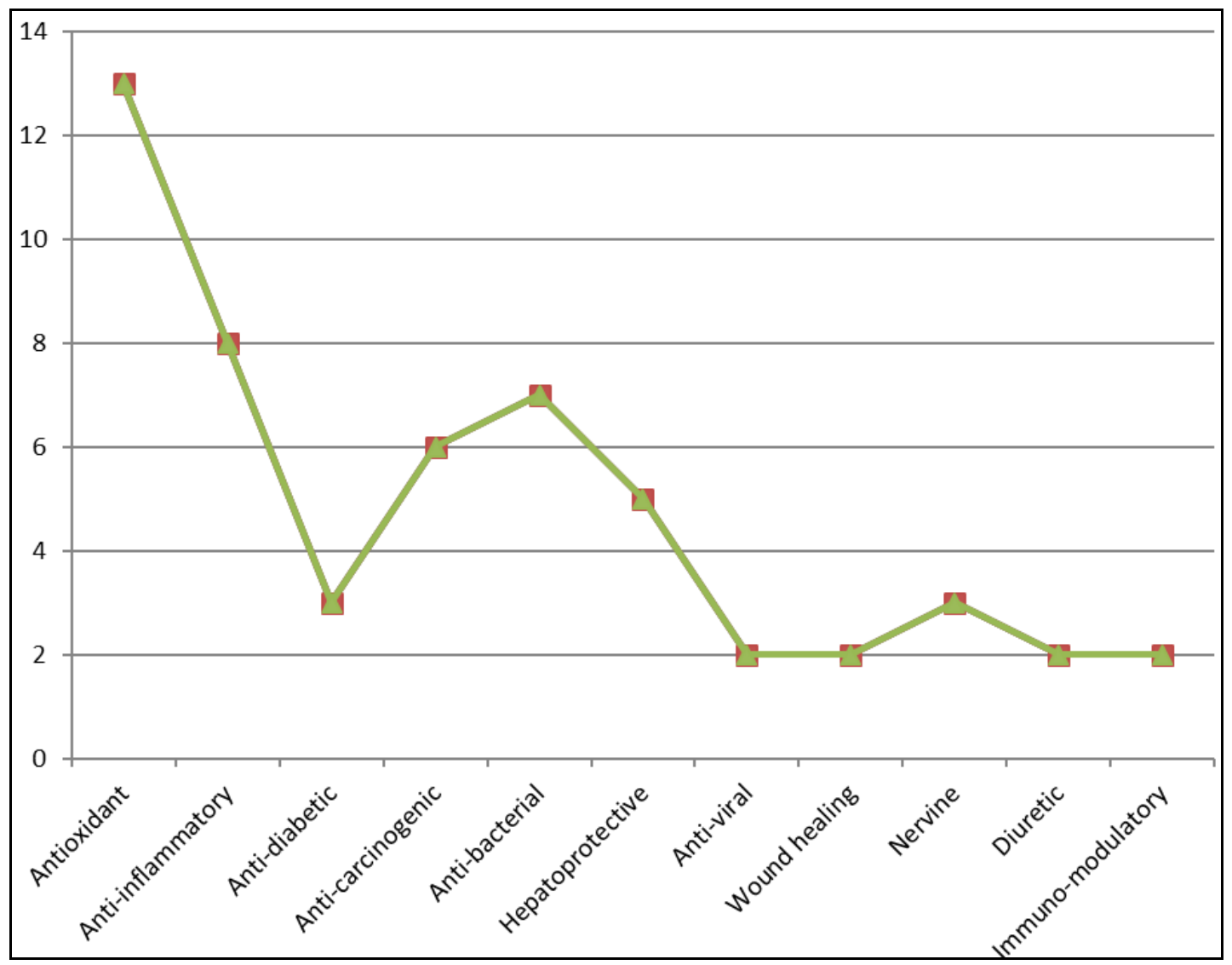

Fig 2: Plants with therapeutic properties in terms of number 


\section{Conclusion}

Wild vegetables have provided native communities the much needed supplements all through even during the unfavourable weather conditions. The fact that traditional rural communities were and still are nutritionally successful, even during periods of drought, affirms the importance of recognizing and utilizing traditional wild food resources. Compared to conventional cultivated species, wild vegetables are hardy, require less care, and are a rich source of important micronutrients, vitamins and minerals needed to maintain health and promote immunity against infections besides providing food security.

Wild vegetables are among the most important sources of natural antioxidants and have applications against chronic diseases related to oxidative stress. Anti-oxidants from our diet play an important role in helping endogenous antioxidants for neutralization of oxidative stress. The nutrient oxidant deficiency is one of the causes of numerous chronic and degenerative pathologies. (Lien et al, 2008). Lack of proper knowledge on the nutritive and medicinal value of wild vegetables has been an important deterrent to their general acceptance and utilization and regards them as inferior to use. Research on potentially exploitable wild vegetable plant species has to be conducted as this would promote their increased utilization. Such information would help in addressing nutritional and healthcare deficiency of Indian communities as this part of India is highly vulnerable to life style and degenerative diseases. This information should be useful for both product development and awareness raising. These wild vegetables could be recommended as a source of bioactive compounds with potential therapeutic compounds and health benefits.

\section{Conflict of Intrest}

Nil

\section{References}

1. Veeru P, Mishra P Kishor, Mishra M. Screening of medicinal plant extracts for antioxidant activity. J Med. Plant Res. 2009; 3(8):608-612.

2. Maiyo ZC, Ngure RM, Matasyoh JC, Chepkori R. Phytochemical constituents and antimicrobial activity of leaf extracts of three Amaranthus plant species. J Biotec. 2010; 9(21):3178-3182.

3. Najmeh K, Seddigheh A, Hossein M, Parvin M. Effects of Amaranthus caudatus extract and lovastatin on atherosclerosis in hypercholesterolemic rabbits. J Med. Plants Res. 2010; 4(5):355-361.

4. Kitchlu S, Mehrotra, Singh PK, Sumitra. Progesterone potentiating effect of Dipsacus mitis D. Don for its contraceptive action in hamster. Ind. J Exp. Bio. 1999; 37(04):402-405.

5. Kar A, Borthakur SK. Medicinal plants used against dysentery, diarrhoea and cholera by the tribes of erstwhile Kameng district of Arunachal Pradesh. Ind. J Nat. Pro and Res. 2008; 7(2):176-181.

6. Shale TL, StirkWA, van Staden J. Variation in antibacterial and anti-inflammatory activity of different growth forms of Malva parviflora and evidence for synergism of the anti-inflammatory compound. J Ethnopharmacol. 2005; 96(1, 2):325-330.

7. Hussein F, Hassan R, Hijazi A, Badran B. Preliminary phytochemical screening and extraction of polyphenol from stems and leaves of Lebanese plant Malva parviflora L. Int. J Curr. Pharm. Res. 2012; 4(1):55-59.

8. Barros L, Carvalho AM, Ferreira I. Leaves, flowers, immature fruits and leafy flowered stems of Malva sylvestris: A comparative study of the nutraceutical potential and composition. Food Chem. Toxicol. 2010; 48(6):1466-1472.

9. Razavi SM, Zarrini G, Molavi G, Ghasemi G. Bioactivity of Malva Sylvestris L., a Medicinal Plant from Iran. Iran J Basic Med Sci. 2011; 14(6):574-579.

10. Bonjar S. Evaluation of antibacterial properties of some medicinal plants used in Iran. J Ethnopharmacol. 2004; 94(2, 3):301-305.

11. Ata S, Farooq F, Javed S. Elemental profile of 24 common medicinal plants of Pakistan and its direct link with traditional uses. J Med. P. Res. 2011; 5(26):61646168.

12. Bhandarkar MR, Khan A. Antihepatotoxic effect of Nymphaea stellata willd. Against carbon tetrachloride-induced hepatic damage in albino rats. J Ethnopharmacol. 2004; 91(1):61-64.

13. Raja MKM, Sethiya NK, Mishra SH. A comprehensive review on Nymphaea stellata: A traditionally used bitter. J Adv. Pharm. Tech. Res. 2010; 1(3):311.

14. Samuelsen AB. The traditional uses, chemical constituents and biological activities of Plantago major L. A review. J Ethnopharmacol. 2000; 71(1, 2):121.

15. Chiang LC, Chiang W, Chiang MY, Lin CC. Antiviral activity of Plantago major extracts and related compounds in vitro. Antiviral Res. 2002; 55(1):53-63.

16. Chiang LC, Chiang W, Ching C. In Vitro Cytotoxic, Antiviral and immunomodulatory effects of Plantago major and Plantago asiatica. Am J Chin Med. 2003; 31(2):225-232.

17. Chan K, Islam MW, Kamil M, Radhakrishnan R, Zakaria MNM, Habibullah $\mathrm{M}$ et al. The analgesic and anti-inflammatory effects of Portulaca oleracea L. subsp. sativa (Haw.) Celak. J Ethnopharmacol. 2000; 73(3):445-451.

18. Rashed AN, UAfifi F, Disi AM. Simple evaluation of the wound healing activity of a crude extract of Portulaca oleracea L. (growing in Jordan) in Mus musculus JVI-1. J Ethnopharmacol. 2003; 88(2, 3):131136.

19. Lim YY, Quah EPL. Antioxidant properties of different cultivars of Portulaca oleracea. Food Chem. 2007; 103(3):734-740.

20. Karimi G, Hosseinzadeh H, Ettehad N. Evaluation of the gastric antiulcerogenic effects of Portulaca oleracea L. extracts in mice. Phytother. Res. 2004; 18(6):484-487.

21. Habtemariam S, Harvey AL, Waterman PG. The muscle relaxant properties of Portulaca oleracea associated with high concentrations of potassium ions. J Ethnopharmacol. 1993; 40(3):195200.

22. Anusha M, Venkateswarlu M, Prabhakaran V, Shareen Taj S, Pushpa Kumari B, Ranganayakulu D. Hepatoprotective activity of aqueous extract of Portulaca oleracea in combination with lycopene in rats. Ind. J Pharm. 2011; 43(5):563. 
23. Shobeiri SF, Sharei S, Heidari A, Kianbakht S. Portulaca oleracea $\mathrm{L}$. in the treatment of patients with abnormal uterine bleeding: a Pilot clinical trial. Phytother. Res. 2009; 23(10):1411-1414.

24. Ghosh L, Gayen JR, Murugesan T, Sinha S, Pal M, Saha BP. Evaluation of purgative activity of roots of Rumex nepalensis. Fitoterapia. 2003; 74(4):372-374.

25. Sharma RS, Mishra V, RS, Seth N, Babu CR. Antifungal activity of some Himalayan medicinal plants and cultivated ornamental species. Fitoterapia. 2008; 79(7, 8):589-591.

26. Ghosh L, Gayen JR, Sinha S, Pal S, Pal M, Saha BP. Antibacterial efficacy of Rumex nepalensis Spreng. Roots. Phytother Res. 2003; 17(5):558-559.

27. Hussain F, Hameed I, Dastagir G, Khan I, Ahmad B. Cytotoxicity and Phytotoxicity of some selected medicinal plants of the family Polygonaceae. Afr. J Biotechnol. 2010; 9(5):770-774.

28. Gautam R, Karkhile KV, Bhutani KK, Jachak SM. Anti-inflammatory, cyclooxygenase (COX)-2, COX-1 inhibitory, and free radical scavenging effects of Rumex nepalensis. Planta Medica. 2010; 76(14):1564-1569.

29. Yadav SK, Jain S, Pundir P, Jadon RK, Sharma S, Khetwal A et al. Antimicrobial activity of different extracts of roots of Rumex nepalensis Spreng. Ind. J Nat. Prod. Res. 2011; 2(1):1564-1569.

30. Anusuya N, Gomathi R, Manian S, Venkatarame G, Sivaram, Menon A. Evaluation of Basella rubra L., Rumex nepalensis Spreng and Commelina benghalensis L. for antioxidant activity. Int. J Pharmac Sci. 2012; 4(3):714-720.

31. H-Jin Jeon, H-Jung Kang, H -Joo Jung, Y-Sook Kang, C-Jin Lim, Y -Myeong Kim et al. Anti-inflammatory activity of Taraxacum officinale $\mathrm{J}$ Ethnopharmacol. 2008; 115(1):82-88.

32. Schütz K, Carle R, Schieber A. Taraxacum-A review on its phytochemical and pharmacological profile. J Ethnopharmacol. 2006; 107(3):313-323.

33. Clare BA, Conroy RS, Spelman K. The Diuretic Effect in Human Subjects of an Extract of Taraxacum officinale Folium over a Single Day. J Alter. Complement. Med. 2009; 15(8):929-934.

34. Colle D, Arantes LP, Gubert P, Almeida da Luz SC, Athayde ML, Rocha JBT et al. Antioxidant Properties of Taraxacum officinale Leaf Extract Are Involved in the Protective Effect against Hepatoxicity Induced by Acetaminophen in Mice. J Med. Food. 2012; 15(6):549556.

35. Zargar BA, Masoodi MH, Ahmed B, Ganie SA. Phyto constituents and therapeutic uses of Rheum emodi wall. ex Meissn. Food Chem. 2011; 128(3):585-589.

36. Mukherjee P, Saha K, Balasubramanian R, Pal M, Saha BP. Studies on psychopharmacological effects of Nelumbo nucifera Gaertn. Rhizome extract. Journal of Ethnopharmacology. 1996; 54(2, 3); 63-67.

37. Lone PA, Bhardwaj AK, Bahar FA., A study of some locally available herbal medicines For the treatment of various ailments in Bandipora District of J\&K, India. Int. J Pharm. Bio. Sci. 2013; 4(2):164-178.

38. Mukherjee PK, Balasubramanian R, Saha K, Saha BP, Pal M. a review on Nelumbo nucifera Gaertn. Ancient Science of life. 1996; 15(4):268.
39. Khan FA, Khattak MR, Shah SMM, Zahoor M, Shah SM. Screening of Crude Phytochemicals and Antimicrobial Activities of Selected Medicinal Plants of Peshawar Region Khyber Pakhtoon Khawa Pakistan Middle-East. J Scientific Res. 2011; 9(2):3712-3716.

40. Kokanova Z, Nedialkov NPT, Nikolov SD. Pharmacognostic investigations of the aerial parts of Chenopodium foliosum Asch and radical-scavenging activities of five flavonoids isolated from methanol extract of the plant. Pharmacog. J. 2014; 6(4):43-48.

41. Zeipiņa O, Alsiņa I, Lepse L, Dūma M. Anti oxidant activity in nettle (Urtica dioica L.) And garden orache (Atriplex hortensis L.) Leaves during vegetation period. Chem. Tech. 2015; 66(1):29-33.

42. Tsewang Rinchen, Narendra Singh. Exploring nutritional potential of Atriplex hortensis. Ind. Hort. 2015; 60(2):16-17.

43. Niwano Y, Saito K, Yoshizaki F, Kohno M, Ozawa T. Extensive screening of herbal extracts with potential antioxidant properties. J Clinic. Biochem. Nutr. 2011; 48(1):78-84.

44. Dalar A, Türker M, Konczak I. Antioxidant capacity and phenolic constituents of Malva neglecta Wall and Plantago lanceolata L. from Eastern Anatolia Region of Turkey. J Herb. Med. 2012; 2(2):42-51.

45. Gálvez M, Mart C, Cordero M, López-Lázaro, Cortés F, Marı Jesús Ayuso. Cytotoxic effect of Plantago spp. on cancer cell lines. J Ethnopharm. 2003; 88(2, 3):125130.

46. Beara LI, Lesjak MM, Orcica DZ, Simin ND, Cetojevic-Simin DD, Bozin BN et al. Comparative analysis of phenolic profile, antioxidant, antiinflammatory and cytotoxic activity of two closelyrelated Plantain species: Plantago altissima L. and Plantago lanceolata. Food Sci. Tech. 2012; 47:64-70.

47. Vigo E, Cepeda A, Gualillo O, Perez-Fernandez R. Invitro anti-inflammatory activity of Pinus sylvestris and Plantago lanceolata extracts: effect on inducible NOS, COX-1, COX-2 and their products in J774A.1 murine macrophages. J Pharm. Pharm. 2005; 57(3):383-391.

48. Girija K, Lakshman K, Udaya C, Sachi GS, Divya T. Anti-diabetic and anti - cholesterolemic activity of methanol extracts of three species of Amaranthus. Asian Pac. J Trop Biomed. 2011; 1(2):133-138.

49. Broekaert WF, Mariën W, Terras FR, MF DB, Proost P, Damme $\mathrm{V}$ et al. Antimicrobial peptides from Amaranthus caudatus seeds with sequence homology to the cysteine/glycine-rich domain of chitin-binding proteins. Biochem. 1992; 31(17):4308-4314.

50. Lee N, Choi J, Koo B, Ryu S, Han Y, Lee S et al. Antimutagenicity and Cytotoxicity of the Constituents from the Aerial Parts of Rumex acetosa. Bio. Pharm. Bulletin. 2005; 28(11):2158-2161.

51. Orhan I, Kartal M, Abu-Asaker M, Şenol FS, Yilmaz G, Şener B. Free radical scavenging properties and phenolic characterization of some edible plants. Food Chem. 2009; 114(1):276-281.

52. Mariya A Qurieshi, Salim Khan SM, Muneer A Masoodi, Uruj Qurieshi, Quratul Ain, Yasmeen Jan et al. Epidemiology of Cancers in Kashmir, India: An Analysis of Hospital Data. Adv Prev Med, 2016. Published online 2016 Jul 5. doi: 10.1155/2016/1896761.Acessed 5 March 2018. 
53. Rasool MT, Lone MM, Wani ML, Afroz F, Zaffar S, Mohib-ul Haq M. Cancer in Kashmir, India: Burden and pattern of disease. J Can Res Ther. 2012; 12(8):243-46.

54. Lien Ai Pham-Huy, Hua He, Chuong Pham-Huy. Free Radicals, Antioxidants in Disease and Health. Int J Biomed Sci. 2008; 4(2):89-96.

55. Subzar Ahmad Sheik. Ethno-medicinal uses and pharmacological activities of lotus (Nelumbo nucifera). Journal of Medicinal Plants Studies. 2014; 2(6):42-46

56. Srivastava TN, Rajasekaran S, Badola DP, Shah DC. An index of the available medicinal plants, used in Indian system of medicine from Jammu and Kashmir State. Ancient Sci Life. 1986; 6:49-63.

57. Petrovic J, Stanojkovic A, Comic LJ, Curcic S. Antibacterial activity of Cichorium intybus. Fitoterapia 2004; 75(2-4):737-739.

58. Malik A, Khuroo A, Dar GH, Khan ZS. Ethnomedicinal uses of some plants in Kashmir Himalayas. IJTK 2011; 10(2):362-366.

59. Khan ZS, Khuroo A, Dar GH. Ethnomedicinal survey of Uri, Kashmir Himalayas. IJTK 2004; 3(4):351-357.

60. Kaul MK. Medicinal Plants of Kashmir and Ladakh. Indus Publishing Company, New Delhi, 1997.

61. India: Health of the Nation's States- The India StateLevel Disease Burden Initiative. Indian Council of Medical Research (ICMR), Department of Health Research, Ministry of Health and Family Welfare, Govt. of India, New Delhi, 2017.

62. Hamayun S, Khan S, Qureshi R, Zahid ullah. Indigenous plant resources and their utilization practices in village populations of Kashmir Himalayas Pak. J Bot. 2012; 44(2):739-745.

63. Rajoriya CM, Choudhary RG, Shah IA, Rawat RS, Jat BL. Ethno-medicinal Survey of North Kashmir with Special Reference to Bandipora. I J Res A Sci En Tech (IJRASET). 2016; 4(11):95-106. 